\title{
RESEARCH OF ELECTORAL PROCESSES IN THE INITIAL STAGES OF FORMATION OF ELECTORAL SOCIOLOGY
}

\author{
Jiyanmuratova Gulnoz Sherbutaevna \\ Associate Professor of \\ the National University of \\ Uzbekistan
}

Article DOI: https://doi.org/10.36713/epra4597

\begin{abstract}
ANNOTATION
This article discusses a brief history of the first attempts to study electoral processes by the polling method in the initial stages of the development of electoral sociology as an independent science at the turn of the 19th-20th centuries in the USA.
\end{abstract}

KEYWORDS: electoral sociology, electoral process, straw polls, selective method

\section{Джиянмуратова Гулноз Шербутаевна - доцент Национального университета Узбекистана,}

\section{ИССЛЕДОВАНИЯ ИЗБИРАТЕЛЬНЫХ ПРОЦЕССОВ В НАЧАЛЬНЫХ ЭТАПАХ СТАНОВЛЕНИЯ ЭЛЕКТОРАЛЬНОЙ СОЦИОЛОГИИ}

Аннотация. В данной статье рассматривается краткая история первых попыток изучения электоральных процессов методом опроса в начальных стадиях становления электоральной социологии как самостоятельной науки в на рубеже XIX-XX веков в США.

Ключевые слова: электоральная социология, избирательный процесс, соломенные опросы, выборочный метод

Электоральная социология на сегодняшний день является одной из актуальных и важнейших дисциплин для Республики Узбекистан, определившей путь демократического развития. В Национальном университете Узбекистана имени Мирзо Улугбека начиная с 2018-2019 учебного года в учебный план по подготовке магистров по специальности «5А210101 - Социология» был включен курс «Электоральная социология». В связи с этим изучение истории становления этой науки, истории становления практики изучения избирательных процессов в целом стало 
актуальной для системы высшего образования Республики Узбекистан.

Электоральная социология (лат. eligo выбор) или социология выборов - это область социологии, которая изучает ряд вопросов, связанных с поведением населения в избирательных кампаниях, включая изучение социальных сообществ и отдельных граждан, факторов, влияющих на участие в выборах.

В истории становления электоральной социологии как науки, мы, безусловно как и многие исследователи этой проблемы, признаем роль США. США является родиной также основных школ, методов и методик этой дисциплины. Избирательные процессы, особенно электоральное поведение, были предметом социальных исследований в США со второй половины XIX века. В связи с этим стоит отметить, что первый этапом в развитии электоральной социологии считается создание специальной системы подсчета голосов в день выборов, с целью прогнозирования результатов голосования. В истории социологии это явление возникло под названием «соломенные опросы». Американское издание «New Political Dictionary» признаёт Джона Селдена автором термина «соломенные опросы» (straw polls), который написал следующие строки: «Возьмите солому и подбросьте её в воздух - вы сможете увидеть, куда дует ветер». Этот термин не сразу же был введен в научный оборот, но в 1866 году газета «Clevel and Leader» опубликовала статьи со следующими строками: «...соломенный опрос, проведённый вчера в поезде, показал...» $[1,132]$.

Исследователь избирательных опросов К.С. Франкович цитирует заметку, опубликованную в американской газете Тhe American Watchman и Delaware Advertiser в 1824 году: «Мы призываем наших уважаемых граждан принять участие в этой инициативе - выявлении мнений населения. Пусть политики в Вашингтоне и в других местах знают волю людей и, даже если это не решит проблему, люди по крайней мере получат информацию ... » [2, 104-109].

Б.3. Докторов своей книге «От соломенных опросов к постгэллаповским опросным методам» предлагает разделить первый этап становления электоральной социологии на три периода [3]:

$\checkmark$ предыстория соломенных опросов (1789-1824);

$\checkmark$ период становления и расширения системы соломенных опросов (18251915);

$\checkmark$ эпоха журнала «Literary Digest» (1916-32).

Предыстория соломенных опросов отмечается периодом становления института президентства в США. В этот период только белые, финансово независимые мужчины, постоянно проживающие в избирательном округе имели право голоса, они отмечали свой выбор в специальных регистрационных книгах, бюллетеней не было. А также стоит отметить, что администрацией Джефферсона на рубеже XVIIIХIX вв. регулярно проводились опросы предпочтений избирателей.

Исследователь истории соломенных опросов Т. Смит обращает внимание на то, что политические группы, заинтересованные в предвыборных прогнозах, переключились на оценку возможных результатов президентских выборов 1824 года уже в начале 1821 года [4, 2136]. Во время компании в 1824 года были использованы несколько методов сбора информации. Т. Смит предложил назвать опросы этого периода «протосоломенными опросами», так как в проведении этих опросов не учитывались социальные характеристики электората.

Предполагается, что результаты первых двух «соломенных опросов» были опубликованы в июле 1824 года. Впервые в стране 24 июля 1824 года в газете «Harrisburg Pennsylvanian» были опубликованы результаты опроса жителей городка Вилмингтона (Wilmington), штат Делавер. В августе того же года газета «Raleigh Star» сообщала об итогах опроса в штате Северная Каролина [5, 10]. Поэтому некоторые исследователи приходят к выводу, что электоральная социология возникла как наука при создании института президентских выборов в США.

Первые опросы проводились в основном газетными публикациями, и у журналистов не было достаточных навыков в методике проведения опроса и методе выборки. Основное внимание было уделено максимальному объему информации. Не было четкого контроля над сбором данных в прессе. Заполненные анкеты были в основном возвращены в течение нескольких недель, и поэтому было невозможности определения динамики предвыборных настроений.

Сьюзан Хербст пришла к выводу, что соломенные опросы начались в 20-х годах XIX века, но стали популярным только в середине XIX века. Хербст называет этот период периодом «народных» опросов [6].

Начиная с 1840-х годов клиентам отелей стали предлагать возможность указывать в регистрационной книге, за кого они хотели бы проголосовать в ходе президентской избирательной кампании. В 1851 году один из помощников газеты в Миссисипи провел 800 интервью в 17 округах, где результаты выборов были неопределенными. Газета смогла точно 
прогнозировать результаты выборов в 15 избирательных округах.

Ко второй половине XIX века соломенные опросы стали более сложным и многоступенчатым исследованием. В частности, в 1883 году газета «The Boston Globe» использовала инновационный метод сбора данных для прогнозирования результатов выборов, за день до выборов наблюдатели были направлены в отдельные избирательные округа, а затем результаты государственных выборов были предсказаны на основе их отчетов. Другие издания, в том числе Chicago Records, также провели опрос в размере 60000 долларов за этот период, точно прогнозируя результаты выборов [7]. Позднее количество изданий, проводящих подобные опросы, расширилось. В частности, «Literary Digest»- самый успешный из всех.

«Literary Digest» начал проводить соломенные опросы начиная с 1916 года. В 1920 году журнал раздал 11 млн карт, в 1924 - 16,5 млн, в 1928 - 18 млн карт. И все прогнозы журнала о результатах выборов были точными. Прогноз 1932 года оставался самым точным в истории журнала: между официальной статистикой и прогнозом журнала была разница только лишь на 1,4 \% голосов. Таким образом, «Literary Digest» никогда не ошибался в своих прогнозах, предсказывая результаты президентских выборов с 1920 по 1932 год, тем самым увеличивая количество подписок на два миллиона экземпляров [3].

Соломенные опросы стали важным этапом в развитии электоральной социологии и заложили основу для дальнейшего развития научных методов и методик электоральной социологии.

Исследования Клода Робинсона сыграли важную роль в изменении отношения к «соломенным опросам». В 1935 году Джордж Гэллап пригласил Клода Робинсона в институт, который он основал. Президентские выборы 1936 года, стали соревнованием между соломенными опросами журнала «Literary Digest» и выборочным опросом Джорджа Гэллапа. В результате победил Гэллап и начался новый период электоральных исследований Джоржа Гэллапа. Гэллап внес качественные изменения в ряд методов и методик изучения избирательных процессов, в первую очередь он разработал и усовершенствовал методику выборки избирательных опросов.

В конце 30-х годов ХIX века электоральная социология вступила в стадию институционализации. Этот этап характеризуется появлением исследовательских центров, проводящих исследования политических взглядов и поведения избирателей. Кроме того, было ускорено формирование профессионального сообщества, и в университетах США начинается преподавание электоральной социологии как самостоятельной дисциплины. Итак, с этого периода мы можем сделать вывод, что электоральная социология начала проявлять себя как совершенно самостоятельная наука.

\section{Список литературы}

1. См.: Политическая сочиология в 2 ч. Часть 2. Изд. 2-е, исп. и доп. Учебник и практикум для академического бакалавриата / под ред. Т. В. Евгеньевой. - М.: Юрайт, 2018. - С. 132.

2. Frankovic K.A. Election Polls. The Perils of Interpretation // Media Studies Journal. 2000. Vol. 14. No. 1. P. 104-109.

3. См.: Докторов Б.3. От соломенных опросов $\kappa$ постгэллаповским опросным методам. - М.: Радуга, 2013. 72 c

4. CM.: Smith T. The First Straw? A Study of the Origins of Election Polls // Public Opinion Quarterly. 1990. Vol. 54. No. 1. P. 21-36.

5. Докторов Б. 3. Три вехи в истории общественного мнения: 1824-1936-2016 годы / Вестник Сургутского государственного едагогического университета. № 2 (47) 2017. - C. 10.

6. Herbst S. 1993. Numbered Voices. How Opinion Polling Has Shaped American Politics. Chicago: University of Chicago Press. 235 p.

7. CM.: Gallup G., Rae S. F. The Pulse of Democracy: The Public-Opinion Poll and How It Works. New York: Simon and Schuster. 1940. 